\title{
PLAGIARISM, CHEATING AND ACADEMIC DISHONESTY - HAVE YOU BEEN THERE?
}

\author{
Matthew FAWKNER and Greta KEREMIDCHIEVA
}

\section{Let's Set the Scene}

"This is superior work," wrote a professor on a student's paper. It was excellent when Saint Thomas Aquinas wrote it just as it is today. Saint Thomas gets an A. You get an F. ${ }^{1}$

\section{Just Reflect on This Position?}

The past five years haven't been easy. Ned's studies have been intensive. He'll be glad to ditch that part-time job which has left him with little sleep, practically no energy and poor concentration that has dogged him through his law lectures for years. Without that night job Ned would never have made it through, but the money covered the cost of his studies. Ned wonders what it will be like to enjoy social occasions again free from that nagging thought of study. He has used every available minute to complete those 'damned assignments' and the never-ending readings that seem to have always been part of his law degree. It certainly hasn't been easy for him.

On top of all of his problems, living away from home has created stressors that he had not experienced before - like living in student quarters, managing a pile of washing (when did he ever last iron something?), eating regularly and just being himself. Just surviving has taken all of his wits and available 'living skills.' Thank God that Ned's final examinations are only weeks away. He reflects on the possibilities - Ned Smith, BA, LLB, DipGradLawPrac - Legal Practitioner. It all sounds very nice to him.

Lining-up in the queue to collect his final 24-hour 'take-home exam' Ned's stomach aches as he ponders whether he has prepared adequately. Finally, he collects his paper and as he scans the questions a wry smile comes to his face. He recognises a question that was part of his preparatory studies. 'Oh dear' he mutters, 'the remainder of the paper involves those time consuming and complex questions - the ones that I 
have slogged through before in this type of exam.' As Ned rushes back to his room he mentally analyses his exam tactics - do the more difficult questions first and leave the easiest until last.

As the early hours of the morning rush by, Ned remembers that he hasn't eaten. About eight hours remain until 'hand-in time'. Time has got away from him. He has taken too long on the more difficult questions and all of the questions must be answered. Now to the easiest part. Suddenly, Ned is consumed by fatigue. He needs to 'put your head down' for a few hours. Four hours sleep will refresh his tired brain.

A split second after the alarm rings Ned finds that his calculations were wrong. Panic runs through his mind as he realises that he has overslept. Three hours until 'hand-in time.' Suddenly, a possible solution comes to him. He scrambles through files in his laptop. Finally a solution is at hand. Ned finds the essay on the internet that he had mentally recalled earlier. It has been written by a small-time academic from a distant overseas university. He ponders: 'Is this answer my saviour'? Who will know? Only $23 / 4$ hours remains before 'hand-in' time. The lethargy from little sleep and no food is proving to be a powerful stimulant. The ethics of 'cheating' tugs at Ned's tied 'grey matter.' He recalls the rules on 'Academic Dishonesty' which were part of his 'Learning Contract' which he signed in first year almost five years ago. His eyes close as he dreams: "I don't have much time. Surely no one will find out? Yes, just a few small changes - after all, it is written in my style..."

\section{Our Aim}

Our aim in this essay is to discuss the domain of cheating, plagiarism and academic dishonesty and the sources of this misbehaviour. Various approaches to this behaviour will be explored so that educators and academic leaders better understand why those students who cheat and plagiarise risk their study future by choosing this unfortunate path. An attempt will be made to look at approaches to encourage and promote original cognition, quality research and academic honesty. The suggestions made here should be of benefit to the Partnership for Peace (PfP) Learning Management System (LMS) as they would be to any equivalent LMS.

\section{Have You Been There?}

Anyone who has undertaken complex tertiary studies, perhaps mixed with other demands on life, i.e. the need to work to support their studies, have all probably suffered like Ned Smith. Those of us who have studied using the luxury provided by the array of learning available on the Internet will know the plethora of information that is available. Thousands upon thousands of files all accessible through web providers such as 'Google,' 'Altavista' and 'Excite' (to name only a few) provide an 
almost limitless source of information, data, figures and research. Perhaps the very fact that you cannot access any information in these computer-based web sites without making a copy adds to the temptation to cheat, or plagiarise. ${ }^{2}$ One must also ask whether there needs to be some sort of international treaty regulation imposed on the acquisition of information from Internet sources. Are the 'self-regulatory' mechanisms suggested by McCloskey to produce doctrine on the 'Law of the Internet' sufficient to ensure that ethical standards will be maintained by Internet users? ${ }^{3}$ We will explore this area a little later in this essay.

Apart from the Internet, almost all academic institutions are supported by libraries which are crammed with reference material - books, magazines, journals, newspapers, databases, on-line services, etc. The assembled throng of research material just goes on and on, as does the lure to use it illegally.

Academic dishonesty is not simply the pursuit of devious students. It abounds in all areas of academia. A case involving a six-month inquiry headed by a former Chief Justice of the Australian High Court has found a senior Australian university Headof-Department guilty of serious academic misconduct. This misconduct had contravened 'research' guidelines provided by the Australian National Health and Medical Research Council and the Australian Vice-Chancellors' Committee. ${ }^{4}$

\section{Is Cheating Part of Our Culture?}

\section{Starting to Learn - A Proposition}

It has never been easier for a student to source information and to use it constructively to support his or her studies. Likewise, it has never been easier for a student to employ dishonest practices by cheating, or plagiarising the work of others. However, in making this statement we must ask ourselves whether we have been taught, from the very start, to be independent with our cognitive skills. ${ }^{5}$ As children, were we capable of autonomous thought? Were we coached, or mentored to be 'independent thinkers'? Or, were we simply caught-up in the rush to learn without being taught how to achieve independent thought? As we grew into adolescents, how self-reliant were we when it came to expressing ourselves in our own natural way? Did we rely on our juvenile conditioning of mimicry, imitation and learning 'parrotfashion' (indeed, can some of us remember that far back)? Haven't we been taught to rely on the information of others and to build on that source as a reservoir for our acquired knowledge?

While the term 'plagiarism' conjures-up improper practices in our minds, recall that we were all once taught to use 'rote-learning ${ }^{6}$ very early-on in our lives. Our parents, as our foremost mentors, taught us as babies to 'learn by saying' or 'learn by doing'. 
The events of 'acquiring, processing, storing and retrieving information' were the very basis of our early cognitive behaviour. In short, we were sub-consciously 'conditioned' to intake sensory information through the use of cognitive skills employing rhymes, visual patterns, mnemonics, and repetition. Therefore, our thinking functions and knowledge processes relied heavily on a 'schema' designed to instil 'thinking,' 'problem solving,' 'creating' and 'remembering' patterns for the remainder of our lives.

The 1968 work of Atkinson and Shiffrin concluded that the human information storage system relied on: “... a short term memory (sometimes also referred to as a "working memory") and a long term memory." All of this formed the way in which we 'organised' and 'stored' information. Lefrancois was of the opinion that we all employed a process of 'chunking,' that is, storing related items of information in useable chunks into our short-term memory. Here, through 'conditioning', we would process the information into our long-term memory for later recall and use. ${ }^{8}$ However, when it came to children Lefrancois concluded that "... one of the most serious limitations on a young child's ability to understand and solve problems is simply a limitation in the number of items that can be retained in working memory for immediate availability."

The point that we make here is that we, as adults, were conditioned as children to use special skills such as 'learning to learn' ${ }^{10}$ which was later subconsciously adapted in our adult lives as 'metacognition'"1 and subsequently translated into our 'metamemory.' 12 In other words, our early cognitive strategies depended largely on the notions of repetition, visual imagery, rehearsal and mnemonics, all designed to implant the 'information of others' into our very receptive, juvenile brains. If this is the case, has our cognitive skill been conditioned to use the work of others as the basis of our learning patterns? Do we, as adults, subconsciously rely on the learning strategies that we absorbed as children? If this is the case, then are we 'prepared to fail' in our metacognition from a plagiarism point-of-view?

Later, as we developed with age, the pressures and competitiveness imbued by educational systems caused our coping capacities to overload. Good exam results became imperative. We just had to attain high standards. For some of us the stakes become so high that if we were to progress into our wanted field of endeavour, the need for success became intense. One must ask whether this demand placed a further strain on our sub-conscious desire for success.

For some, the anxiety and stress caused by study became too much. Those caught-up in deceptive practice became entrapped in a strategy of academic craftiness with the underlying hope that no one would become aware of their actions. Unknowingly, the 
plight of these individuals was that often the additional work taken to become a successful plagiarist was normally far beyond that required for honest study.

\section{Co-operative Learning}

Today, the contemporary approach to learning utilises many co-operative techniques. The 'buddy system' is one; 'small team exercises' is another. Here, we are encouraged to work together to find solutions and answers to many different quests. We balanced our ideas, we discussed likely effects and we rationalised required results. Our applied effort was known by the term 'synergism.' This exertion, according to Gordon et al., was "... the co-operative action of two or more people working together to accomplish more than they would working separately. It applies the possibility of accomplishing tasks that could not have been done by two people working alone."13

Let's take 'synergism' further. In many successful businesses, 'group related norms,' or 'teamwork,' is considered preferable to individual, or 'self-orientated' effort. Take any organisational structure where teamwork is important. For example, the military and security forces all depend upon a standard of behaviour that encourages group interaction. Many other areas of endeavour rely on group practice.

If we are so reliant in our daily practice on group methods, then shouldn't we examine co-operative evaluation processes, rather than the authoritarian regime of individual testing? For instance, if you were required to undergo a complex medical operation wouldn't you feel better if you knew that a team of surgeons were going to work on you rather than just one, lone, surgeon? This may be an extreme example, but it does relate to the very practice that we all seem to perform every day - cooperative learning and performance. The very same effort that our mothers and fathers urged us to adopt as babies, i.e. group cognition.

Knowing this and understanding that humans are gregarious by nature, should we not facilitate learning (and hence formative assessment systems) that relies on designing collaborative norms and evaluating participatory competencies? Is the somewhat 'autocratic' practice of individual summative testing ambiguous in the majority of our social and workplace circumstances? Let's tie this into the subject of this essay 'cheating and plagiarism.'

\section{Cultural Patterns}

In an investigation conducted by the Australian Press Council into claims by the Australian Chinese Forum that a press report on student plagiarism had been biased, an analysis of the reasons behind the alleged plagiarism led to a number of conclusions ${ }^{14}$ : 
- ... "the slavish respect for authority" in some of the student's countries of origin which was said to encourage a "repetition of approved solutions" in academic work;

- limited library resources in these countries, so that "one way of coping is to duplicate what the teachers say";

- English language difficulties amongst students which prompt the "development of groups around a marginally more competent linguist whose lectures notes are shared by all"; and

- Student's fear of failure, especially when their families have made great sacrifices to send them to Australia.

Those ethical norms adopted by wealthy families are also no bar to incidents involving cheating. In August, 2002 the son of the Prime Minister of Thailand was accused of cheating in university exams, reports Ananova ${ }^{15}$ :

The son of Thailand's prime minister has been caught cheating during a university exam and faces severe disciplinary punishment. Panthongthae Shinawatra, 22, enrolled at Bangkok's Ramkhamhaeng University, was found using "cheat sheets" he had hidden in his pockets, Wiwatchai Kulamat, (sic) according to an examiner. He is the only son of Prime Minister Thaksin Shinawatra, a successful tycoon and the founder of Thailand's biggest telecommunications conglomerate. The prime minister (sic) has refused to comment on his son's actions. The examiner says Panthongthae was removed from the examination room and barred from taking further tests pending an investigation. If he is found guilty, he will be failed in all subjects that he has taken tests for this semester, Wiwatchai says. Panthongthae is studying for a bachelor's degree with political science as major. He became one of the richest men in Thailand after his parents transferred 73.4 million shares or a 25 percent stake in Shin Corp into his name.

\section{Cultural Strains}

The pressure to succeed is often the root cause behind student cheating. Heather Bird discovered the outcome of 'cheating' for 30 law students found-out by the University of Toronto ${ }^{16}$ :

Nobody probably knows this better now than the dirty 30, the University of Toronto law students who gussied up their mid-term marks in order to land prime jobs at big Bay St. firms. They've cheated themselves out of a year of school, a summer job and quite possibly a lucrative career. That seductive shortcut is going to mean a long march back for those who have the stomach to 
stick it out. While the university won't say for sure what's been happening, word has leaked out that a number of these cheaters have already been told they will face one-year suspensions for their duplicity. If they return, the deceit will be noted on their transcripts, which will expose them to their teachers. And even if they do complete their law degree, there's no guarantee they will be called to the bar because the Law Society of Upper Canada requires that candidates be "of good character." Lying, presumably, is not a quality which will stand them in good stead.

\section{Misuse of Modern Technology}

There is little doubt that the use of modern technology has aided individuals who wish to plagiarise and cheat. A report in the well respected South-East Asian newspaper 'The Straight Times' gave this account: “...students have sent questions to friends outside school by e-mail, SMS, and even by photograph using thirdgeneration mobile phones. They receive answers the same way, or through hidden earpieces. As a preventive measure, electronic scanners will be used to stop students cheating in O-level and A-level exams by using Internet-enabled mobile phones which can receive answers through e-mail, pictures and text messages." 17

This is not an isolated case. Further investigation into the use of the SMS messaging system revealed a report in the on-line version of the US newspaper 'The Wall Street Journal": "Twelve students were accused of cheating during an exam at the University of Maryland by receiving the answers by SMS from friends outside the classroom. They were reading off the answer keys posted on the Internet by a professor once the exam began.,"18

\section{Using the Work of Others}

Like plagiarism, the deceitful practice of cheating is part of the continuum of academic dishonesty. Within the academic sphere, cheating is normally associated with the dishonest substitution of work as one's own in exams, tests, or in assessment systems. If we were to be very truthful, we all might have been accused of this practice, at one time or another, in our younger days. If you agree with this proposition, then ask yourself this: 'Why did I do it?' Let's go back to our younger days.

The legal term 'mens rea' deals with the 'guilty mind,' or the 'mental element' that is involved in a particular illegal act or crime. In addition, the principal convention relating to children, i.e. the United Nations 'Convention on the Rights of the Child,' specifies that: ' $a$ child is any person below the age of 18 years. ${ }^{19}$ Knowing this we must also understand that in many jurisdictions there is a presumption that any child 
under the age of 14 years of age ${ }^{20}$ is 'incapable of any culpability, ' that is, the notion of 'doli incapax' concerns the fact that a child does not have the mental capacity to bear the weight of wrongdoing, or criminal acts. Using this argument it can then be assumed that in most cultures children do not necessarily know that substituting the work of others, or cheating, is wrong. Quite the opposite. They are often imbued with the idea that using the work of others will sustain and foster their knowledge. In other words, any learning situation in which there is a system of continued reinforcement will induce 'imitative behaviour. ${ }^{21}$ Is it then possible that we coach our children to be imitators and then once we believe that they have attained independent thought. We then say that they cannot replicate the work of others? Is this psychology correct?

The act of cheating has been studied by Noah and Eckstein and it is their tenet that it is so prevalent within academic institutions that: 'Cheating on important exams occurs in every country of the World'. ${ }^{22}$ Such wayward activity is agreed with by Professor John Croucher, an Australian academic who is also of the opinion that 'cheating in exams has become epidemic'. ${ }^{23}$ In a recorded interview with the Perth offices of the Australian Broadcasting Commission ${ }^{24}$ Professor Croucher postulated that cheating has become so rife within universities that efforts to stem its practice were beyond most universities capacity to deal with it. In some areas he conceded that the very credibility of many universities was in doubt because of this practice. Like Noah and Eckstein, he is of the belief that if exams are to be genuine tests of achievement by individuals, then exams must be 'guarantees of competence ${ }^{25}$ It is difficult to refute this opinion. How do we know this? A US survey conducted on 3000 college aspirants in 1998 revealed this level of academic dishonesty ${ }^{26}$ :

- 80 percent of the country's best students cheated to get to the tops of their classes;

- more than half the students surveyed said that they did not think that cheating was a big deal;

- 95 percent of cheaters said they were not caught;

- 40 percent cheated on a quiz or a test;

- 67 percent copied someone else's homework.

This level of academic dishonesty is confirmed by 'The Center of Academic Integrity' which has also established that: ' $\ldots 80 \%$ of college students admit to cheating at least once. ${ }^{27}$

One must ask whether errant 'cheating' and 'plagiarism' (which we all may have been involved in during our earlier life) can remain in our subconscious thoughts to emerge later on as adults. Some evidence suggests that this may be the case. The founder of 
the 'JCT Center for Business Ethics and Social Responsibility' Dr. Tamari reveals that:

Evidence seems to be mounting that cheating on exams in schools has reached epidemic proportions in almost all Western countries. A recent issue of the READERS' DIGEST describes in gory details the extent of cheating in the United States, and other countries have similar records. It is perhaps easy to dismiss cheating on exams as a form of youthful pranks or misdemeanours. Yet even a cursory examination will show, that in actual fact the mind frame behind such cheating is a preparation for dishonesty in business. The motivation, the evaluation of the action, and the spiritual framework within which cheating on exams exists, all promote unethical behaviour by workers, by employers, and by consumers. From the seemingly small beginnings of such cheating ultimately grow the white collar criminals of the future as well as the dishonest behaviour regarding money and wealth. Any concerted effort in the field of ethical education in business must, of necessity, therefore concern itself also with this phenomenon in the school systems. ${ }^{28}$

Further, Jay Kelman believes that "The problem ... goes beyond the personal desire for money" and that while "We have compartmentalized our lives into religious and secular components" ${ }^{, 2}$ such behaviour has commenced to permeate the code of Jewish law and hence the Jewish faith:

Unfortunately all too often (once is too often) we hear about ritually observant Jews involved in white collar crime; tax evasion, money laundering, embezzlement, and fraud. Perhaps even worse is the attitude that one so often hears in casual conversation. 'I am only an employee so I can't write off any personal expenses', or 'of course I pay my contractor in cash' thereby helping him evade his tax responsibility and thus stealing from the honest taxpayer. In an era where increased stringency has become the norm in so many ritual areas why is it that it is leniency that is the norm in our money dealings? ... Our society idolizes material success. Hence even people who don't need the money to make ends meet are tempted to cheat. Even our religious institutions unwittingly contribute to this problem. ${ }^{30}$

However, for the cheat or plagiarist to successfully mould the work of others so that it adopts their individual style can involve additional tedious and time-consuming effort. More often than not, this additional effort far outweighs the requirement to remain upright and truthful. 


\section{What then is Plagiarism and Academic Dishonesty?}

\section{'Plagiarism' and 'Cheating' Defined}

Lisa Hinchcliffe admits that "Plagiarism is a difficult concept to define. It includes a range of actions from failure to use proper citation to wholesale cheating. A student who plagiarizes may do so unintentionally, or with planful deliberation." ${ }^{31}$

How do we differentiate between the two acts of academic dishonesty? In making a simple comparison between cheating and plagiarism Bricault has likened 'cheating to stealing', whereas 'plagiarism is likened to forgery. ${ }^{32}$

\section{Cheating}

In defining the act of 'cheating,' Bricault is of the opinion that cheating is 'a fraud committed by deception; a trick, imposition, or imposture. ${ }^{33}$ Likening the practice of cheating to 'the academic equivalent of urban crime,' Bricault agrees with the 1997 Oakton Community College study which found that 'cheating' is:

...copying or attempting to copy from another student's work, [or] using or attempting ti use unauthorised information, notes, [and] study aids. ${ }^{34}$

Cheating, or substituting another's work for one's own, is certainly not confined to the academic arena. It is much broader than that. This dishonest action occurs right throughout all levels of society. In many countries legislation has been enacted to prevent such practice. As we have established earlier the fraudulent act of cheating has become an art in some countries.

Consequently, the Bulgarian Copyright Law in its Administrative Regulations states the penalties:

Art 97. Whoever, breaching the regulations in this law, publishes or disseminates products already published ... will be fined ... and the subject of violation will be confiscated. ${ }^{35}$

\section{Plagiarism}

What then is 'plagiarism'? In defining the term 'plagiarism' many differing interpretations are taken, according to the institution concerned. In general terms, 'plagiarism' is:

The intentional submission or application of another individual's work without providing the credit, or acknowledgment for that work in order to profit or gain academic advantage. 
According to Home:

Plagiarism is the conscious manipulation of pre-existing elements in the creation of "aesthetic" work. Plagiarism is inherent in all "artistic" activity, since both pictorial and literary "arts" function with an inherited language, even when their practitioners aim at overthrowing this received syntax (as happened with modernism and post-modernism). ${ }^{36}$

If we accept the above definitions of plagiarism, how then does it apply in practice? While there will always be many forms of plagiarism, the generally accepted examples concern students who submit work as their own which is ${ }^{37}$ :

- A direct copy or duplication (or allowing work to be copied or duplicated) of the intellectual pursuit of another;

- The paraphrasing, or re-wording of work submitted by another in order to substitute the concept, notion or meaning of that work;

- Work that has already been submitted or presented for credit in another academic discipline or subject;

- The collusion or conspiracy to collude with others through the presentation of work in order to gain recognition or profit from such submission or presentation.

As an indication to students on how to avoid plagiarism the Indiana University Bloomington Writing Tutorial Services webpage has provided this clear, simple and effective guidance ${ }^{38}$ :

To avoid plagiarism, you must give credit whenever you use:

- Another person's idea, opinion, or theory;

- Any facts, statistics, graphs, drawings - any pieces of information - that are not common knowledge;

- Quotations of another person's actual spoken or written words; or

- Paraphrase of another person's spoken or written words.

Plagiarism will range from the simplest substitution to the most sophisticated and subtle rearrangement of ideas and concepts. Of course plagiarists range from the dull, unwitting student to the most shrewd and skilful of individuals. Those who are devoid of any original ideas are often the smartest in rearranging the work of others. The rather sad point here is that those who fit into this category are usually those intellectually bright students who have the requisite capability to do well, but are pressured into plagiarising work because of other outside demands. 


\section{Detection of Academic Dishonesty}

Oddly, the very use of computers, which is probably the primary source of information for the plagiarist, is also the plagiarists' nemesis. Sophisticated algorithmic software has been designed to assist in the detection of plagiarism. However, despite this, the fact is that only a very small percentage of plagiarised work is ever detected. There are various reasons for this, from the want to maintain high academic standards by some institutions, to the general laissez-faire displayed by lax academics and assessors. If the systems available to detect plagiarised work were more effective, the resultant discovery of academic dishonesty would be much higher, as would the consequent failure rate for those who are involved with this dishonest practice.

Perhaps the easiest plagiarised work to detect is that work which is copied or reproduced directly from a known source 'word-for-word' without quotation marks and without acknowledgment. Such word-for-word copying is usually quite obvious. Either the standard of the work is far beyond the student's intellectual capacity, or the style, grammatical usage or academic character far outweighs the student's past standards. Despite this, it may also be that the student is not cheating, but is simply unaware of how to correctly acknowledge sourced information.

More subtle plagiarism commences with the re-paraphrased work of others. Here, a student may simply rearrange words and phrases in a text, again without acknowledgement to provide the same conceptual idea produced by the original writer.

Further subtlety occurs when a student may acknowledge a source, but in doing so that student has never actually sourced the information from the original book, article, etc. Again, this may be blatant plagiarism, or it may simply be that the student is unaware how to acknowledge secondary sources. Often it can be detected through minor errors in punctuation or citation which are copied from the secondary source.

The most subtle and difficult to detect work is where a student uses the structure or argument of a source, again without acknowledgment but with the idea to indicate original reasoning as one's own.

\section{A Policy on Academic Dishonesty}

The University Council of the highly respected University of Melbourne has instituted this policy in respect to academic dishonesty and plagiarism:

...that cheating by students in any form is not permitted, and that work submitted for assessment purposes must be the independent work of the 
student concerned (or, where joint work is permitted, of the students concerned). ${ }^{39}$

Similarly, the very notion of academic dishonesty is viewed by the conservative Canadian 'Queens University' as being a most serious academic offence. In 'Academic Regulation 26a' their view of academic dishonesty is:

All forms of academic dishonesty are considered serious offenses within the University community and a student who commits such an offense runs the risk of a range of sanctions including a failure in the course or a requirement to withdraw from the University. Academic dishonesty includes plagiarism as well as any deliberate attempt to gain unfair advantage academically for oneself or others. Dishonest practices include fabrication of data, cheating, or the uttering of false statements related to academic work by a student. Plagiarism means presenting work done (in whole or in part) by someone else as if it were one's own. Plagiarism should be distinguished from co-operation and collaboration. Often, students may be permitted or expected to work on assignments collectively or separately. This is not a problem so long as it is clearly understood whose work is being presented, for example, by way of formal acknowledgment or by footnoting. ${ }^{40}$

\section{Academic Accountability}

Following substantial allegations of plagiarism committed within the University of Newcastle, Australia, both the Chancellor and Vice-Chancellor are set to resign after an incriminating report submitted by the St. James Ethics Centre. ${ }^{41}$ The critical St. James Report commissioned by the university to investigate allegations of plagiarism looked at how the university handled four separate cases involving:

...16 overseas students from Institut WIRA in Malaysia who allegedly copied material from the Internet; a senior academic who allegedly failed to credit one of his honours students when applying for a research grant; and honours student who allegedly plagiarised two other honours students from the same school; and a professor who allegedly plagiarised her own Masters degree and the work of others in a PhD. ${ }^{42}$

The university's governing council, responding to the St. James Centre's report acknowledged that it 'lacked an ethical foundation' for its plagiarism policies, that its policies had been 'applied with a lack of consistency' and that some 35 new initiatives were required in '...developing new and consistent guidelines across the university ${ }^{43}$ Clearly, the two highest university executives had shown that they were responsible and accountable for the actions of their subordinates and the failure by 
their staff to institute satisfactory policy guidelines on the matter of plagiarism and academic dishonesty. ${ }^{44}$

\section{Academic Dishonesty and the Cyberspace}

\section{The 'World Wide Net'}

The manner in which the World has embraced the Internet is astounding. In little more than one decade, e-mail and the Internet have become a preferred source of communication, contact, interaction, exploration, research and study source. Everyday, those who have the privilege of using the Internet will form part of the 'virtual community' - a community which stretches throughout the globe via the 'World Wide Web.' As Ryan has observed:

Before the World was linked by the Internet, hard-to-detect plagiarism required ingenuity and skill. But today, with the click of a mouse, even technologically inept students have access to vast information resources in cyberspace without having to leave the comfort of their dorm rooms. ${ }^{45}$

\section{One Commercial Solution}

One of many available Internet-based approaches to counter cheating and plagiarism is taken by 'Turnitin.com' who believes that 'pre-emptive education is the best means for preventing plagiarism. ${ }^{46}$ According to Turnitin.com, their research “... is designed to help educators and students develop a better understanding of the complex issues surrounding plagiarism in the information age, and to teach the planning, organizational, and citation skills essential for producing quality writing and research." ${ }^{47}$

Unfortunately, these solutions come at a price. No evaluation has been made of the worth of Turnitin.com. It is further recognised that like most other similar Internetbased organisations, answers to specific problems like cheating and plagiarism will almost inevitably require a financial response from either the individual or the academic institution.

\section{Visit 'Schoolsucks.com'}

In discussing novel approaches to plagiarism Emeritus Professor Bruce Leland of Western Illinois University provides a humorous anecdote concerning an on-line webbased organisation which, although it suggests that it is ' $100 \%$ against plagiarism,' is an open web-site 'repository for plagiarizable (sic) papers' available to students. ${ }^{48}$ Leland says: 
In June 1996 a message was emailed to fraternity and sorority chapters across the country advertising a new electronic repository for downloadable college papers. The site was called schoolsucks.com and featured the slogan "Download your Workload." Members of the Alliance for Computers and Writing (ACW) listserve list fumed and argued about plagiarism in general and schoolsucks.com in particular. Kenny Sahr, the author of the site, joined the discussion for a while, defending his work and adding a page for professors to his site, challenging them to join in the fight against plagiarism. ${ }^{49}$

Access to Schoolsucks.com ${ }^{50}$ does indeed show that it uses the slogan 'Download your Workload' in order for you to gain entry to its web- site. Once there, a user must hit a tab labelled 'I hereby agree that School Sucks' in order to progress. On entering this site, an almost unlimited supply of material can be found on a vast array of subjects. The catch is of course that only few students could ever take advantage of this due to the hefty cost that is put against the material. ${ }^{51}$

\section{Copyright}

The rather 'ticklish' issue of copyright needs to be briefly examined if we consider plagiarism. While every nation exercises control over its sovereignty and territory, the international mechanisms which 'control the Cyberspace' are few in number. ${ }^{52}$ This of course raises issues concerning 'copyright.' As Ginsburg points out:

The key feature of the GII (Global Information Infrastructure) is its ability to render works of authorship pervasively and simultaneously accessible throughout the world. The principle of territoriality becomes problematic if it means that posting a work on the GII calls into play the laws of every country in which the work may be received when ... these laws may differ substantively. ${ }^{53}$

While almost all instances of plagiarism breach the very notion of "copyright' ${ }^{54}$ it should be understood that copyright does not protect ideas, or information, rather, it protects the way in which an idea, or information is expressed in a material form. ${ }^{55}$ The Bulgarian Law of Copyright in its first chapter states under the title 'Subject of the law':

Article 1. This law regulates the relations connected with the creation and dissemination of products of literature, art and science.'

Article 2 'Copyright over products of literature, art and science comes into force for the author with the creation of the product. ${ }^{56}$

The well respected Australian copyright lawyer Nick Dilanchian also says this: 
To understand the legal boundary between the lawful use and plagiarism it is best to start by considering the components of the "form of expression." ... Wholesale copying does not pay. But even partial copying has its dangers. You might delete obviously original aspects of a source of work, change the wording of its sentences and rearrange its paragraphs. But considerable changes that have to be made to wipe out all evidence. In lots of cases breach has been found where remaining trace elements have revealed a plagiarist ancestry. ${ }^{57}$

But given that snippets of concepts, ideas and notions will always remain secreted in an individual's short and/or long term memory, is it not possible that some element of another's original idea will almost always emerge by recall? Dilanchian agrees somewhat by saying that "...the point is that in copyright the difference between permitted free use and theft is a question of degree." 58 But in approaching the dilemma from a writer's viewpoint, Johnson and Post take this approach:

...even in the "real world" ... the author's primary reward has more to do with acceptance in a community and the accumulation of reputational capital through wide dissemination than it does with the licensing and sale of individual copies of works. ${ }^{59}$

While the initial explosion of the Internet was largely without regulation or control, that position is changing. ${ }^{60}$ Putting the international law of 'Comity' ${ }^{61}$ aside, a new area of legal precedent is commencing to emerge as jurisdictional issues arise from breaches of national laws on the Internet. As Fitzgerald suggests in his coverage of the case Dow Jones \& Company Inc. $v$ Gutnick ${ }^{62}$ Cyberspace '...is the epitome of the transnational. ${ }^{63}$ Here, defamatory material which was created in New York and uploaded to a server in New Jersey was available for access on the on-line website of 'The Wall Street Journal' newspaper (a subsidiary of Dow Jones). ${ }^{64}$ It was subsequently found proven that an Australian citizen had been defamed in the Wall Street Journal article as the defamatory materiel could be accessed over the Internet in Melbourne, Australia. The result of this case is that the Internet may not be an open source of materiel as some people think. Certainly, with the matter of defamation, the Gutnick case has shown that individuals may be subject to national jurisdiction if they breach local laws and practices. ${ }^{65}$

The underlying issue is of course the very fact that Cyberspace has made the opportunity to cheat and plagiarise much more easily because information is readily accessible. If one is to follow some sort of 'checklist' on this issue, the guidance given by Dilanchian is worth repeating:

1. Is there copyright in the work being copied? 
2. Is an expression of an idea being copied, not just an idea?

3. Is a substantial part being copied?

4. Is one of the exclusive rights of the copyright owner involved?

5. Is there a defence for copying - fair dealing, an express or implied licence, giving professional legal advice, judicial proceedings, parliamentary library copying, or other defence? ${ }^{66}$

\section{Countering the Problem of Academic Dishonesty}

As with any misconduct which involves breaches of academic policy and rules, clear remedies and guidelines need to be instituted in order to reduce the likelihood of cheating and plagiarism. Few will ever argue that such malpractice will ever be stamped out - such idealism cannot be replicated in today's modern society. Noah and Eckstein have identified four 'major approaches to the task of countering academic misconduct. ${ }^{67}$ These are:

1. Reducing incentives for fraud;

2. Reducing opportunities for fraud and maximizing the probability of detection;

3. Defining and publicizing the limits of acceptable conduct and clarifying, advertising and reinforcing sanctions;

4. Building an academic community that regards cheating, plagiarism and the like as simply unthinkable.

Using the guidance given by Noah and Eckstein, we will reduce the above approaches to three brief proposals to counter cheating and plagiarism. These are: 'Reduce the Need,' 'Provide Alternatives' and 'Lead By Example.' Each will be examined in turn.

\section{Reducing the Need}

The continued upward spiral towards perfection has required both students and academic institutions to pursue academic egoism. Can either party sustain this rush? Is it necessary that every student achieve 99.9 percent in order to be admitted to a higher academic institution? Must academic institutions continually embellish their standards so that they can compete for government based educational grants? Who is at fault here? Is it those who set the standards? Surely it must be. Have educators lost sight of normalcy? What now is average? Is average acceptable?

The point here is that this increase in academic standards forces pressure on students to do well - they must succeed. No one wants to fail. Academia has created a 'scared cow.' While we must accept that competition is healthy, have we gone too far in 
expecting our students to reach almost unattainable heights? Surely this must have a direct correlation on student cheating and plagiarism. Noah and Eckstein think so. They claim that “...inducements to cheat and cut corners are strong, for not only are the potential rewards of doing well great, the penalties for failure are severe. Any successful program to reduce misconduct needs to tackle the prevalence and intensity of competition - no easy task in a society suffused with the spirit of competition." 68

Is it then possible that some academic institutions quietly condone academic misconduct in order to achieve these spiralling standards? After all, brainpower is still brainpower - it has been that way for centuries!

One final point on 'reducing the need' is that students in most Western academic institutions are forced to pay huge fees for their studies. This in effect is a 'contract for learning' between a student and an academic institution so that a student achieves a predetermined outcome. When a student fails, one must ask whether it was the student who failed, or the teacher/ instructor/ professor who failed to get that student to the required knowledge level to pass the test or exam in the first place. While the study burden will always be with the student, it must be accepted that those who are responsible for imparting knowledge on that student must share part of that study burden. Our point here is that it is no longer satisfactory for teachers, lecturers, professors, etc. to simply rely on dull, boring and lifeless modes to impart learning. Surely, with the vast array of "pedagogical' ${ }^{19}$ and 'andragogical' ${ }^{70}$ methods of instruction that are available today, student instructional material must be of the highest standard which reflects all contemporary notions of learning. Academic institutions also must evaluate instruction. Quite often insufficient notice is taken of 'bottom-up feedback,' that is, feedback provided by students themselves. After all, who is now paying for their learning?

\section{Provide Alternatives}

From our earlier discussion it must be evident that students have a greater fear of failing, than they do of getting caught for academic misconduct. Social and even family pressures exist. Even though the penalty for cheating and plagiarism is drummed into students early on in their learning, it still exists. Why? Many teachers, who consider themselves to 'be of the old breed,' will tell you that the attention to grammar and writing skills has declined in recent decades (in favour of other aesthetic subjects). Their view may very well be correct. Have we lost the skill to demonstrate those most important 'writing skills' on our high school students? Are they adequately prepared before they reach university standard? Just think of those students with poor English language skills, or those who use English as a second language. Did the university that you attended have a special department to assist these students? If not, why not? 
No academic with lecturing responsibilities can assume that first year students under their control will be aware how to correctly use citations and to acknowledge another person's work. ${ }^{71}$ Certainly every academic institution that wishes to maintain a high level of academic integrity will need to establish specific style guides for their students. If nothing else, such style guides will lay down writing standards and guidelines to be adopted by both students and the academic staff themselves.

One other alternative to reduce the likelihood of cheating and plagiarism concerns the issuing of 'Learning Contracts.' In effect, a learning contract is “... an agreement negotiated between a learner and a staff supervisor to ensure that certain activities will be undertaken in order to achieve a learning goal and that specific evidence will be produced to demonstrate that the goal has been achieved." ${ }^{, 72}$

Such learning contracts would clearly delineate a student's responsibility in respect to academic honesty. By formulating such a contractual arrangement, a student would not only be aware of his/her responsibilities, but also understand that if he/she transgressed and perpetrated academic dishonesty, then certain disciplinary action may result.

In respect to exams, while every attempt must be made to assist students to prepare for exams (such as trial exams, past papers, exam blueprints, etc.), tests and exams should be set as closely as possible to contemporary 'workplace' specifications. For example, 'open book exams' suit disciplines where students would use reference material in their chosen careers (this follows on from the adage 'never commit to memory anything that you can read in a book'). Such contemporary notions reduce the likelihood of cheating as students know that they can rely on a source of information, providing they have the skills and mastery to find it and apply it.

Teaching and therefore exams should be set to evaluate student knowledge at the higher end of Blooms Taxonomy of Learning. ${ }^{73}$ Tests and exams are, in effect, measuring instruments, and not only should they be competency based in design, but they should reflect workplace practice. Further, tests and exams must have 'face and content validity,' that is, they must measure 'what they are designed to measure' and 'what they are purported to measure. ${ }^{74}$ How often have you come across questions in tests and exams which simply can't be answered?

Lastly, recall the pressure that you were under when you had to 'cram' for exams which were designed to be 'memory tests,' rather than tests of skill, or mastery. Did this place undue pressure on you? Did this pressure ever cause you to consider cheating? 


\section{Lead by Example}

The notion here is that those given the responsibility to teach/ instruct/ tutor students should 'lead by example' and set the acceptable standards in all matters relating to academic honesty. Not only should guidelines be provided which show students how to correctly acknowledge the work of others and how to use citations in written work, but example papers must form part of those guidelines. Given that all academics (certainly those within a university setting) are expected to publish a certain quota of articles, papers and books in their subject area, these writings (which must reflect accepted academic guidelines) should be passed to all students as examples of 'approved work.'

Naturally, students need to be mentored and tutored throughout their studies to ensure that they rise to, and maintain the required standard. This, when coupled with the notion of 'learning contracts,' should set the accepted criterion for academic honesty within any academic institution.

Finally, those responsible for the formulation of academic policy concerning cheating, plagiarism and academic dishonesty must be accountable to their governing boards should they fail to ensure that proper policies exist within their institution. Like both the Chancellor and Vice-Chancellor of the University of Newcastle, Australia, they must be fully accountable to their governing superiors and their actions (or lack thereof), be totally transparent in the event that their academic management and leadership is found wanting.

\section{Conclusion}

The problem of cheating and plagiarism plainly exists. It is present not only in the academic sphere, but also in every circle of society where students, institutional staff and other persons are challenged with high-stake tests, examinations and career betterment. Often, severe competition places these individuals under pressure to succeed. The option, that some resort to, is cheating, plagiarism and academic dishonesty.

Faced with the fear of failure, in order to sustain their present or future status, some individuals are tempted by the abundance of source materials such as those available on the Internet. Here free access and the temptation to copy information provide a ready temptation for some. In addition, the likelihood of being detected and subsequently punished is remote.

Where academic study involves distance learning the appeal to use the work of others is even greater due to the physical remoteness between the student and the instructor, or tutor. One preventive strategy and hence an aid to credibility is that assessment in 
distance learning courses should be conducted under residential conditions where the students are required to meet their assessment criteria under controlled conditions such as in the physical presence of their instructor, where they must answer questions about their study or research, or to comment or defend their written dissertations or presentations. Although these physical requirements are not always easy to administer, if a distance learning course does deliver some form of 'recognition of learning,' then the assessment practices used must be credible and capable of being defended against accusations of cheating and academic dishonesty.

To prevent cheating, plagiarism and academic dishonesty, it is important that students be made aware that this misbehaviour is a serious breach of academic honesty. Every worthwhile academic institution must elaborate an institutional policy on academic dishonesty, including clear guidelines on cheating and plagiarism and the correct academic procedures to acknowledge sourced information. Some of the measures discussed to counter the problem of academic dishonesty should be considered by educators and institutional leaders in order to promote quality research and cognition and thereby reduce the likelihood of academic dishonesty.

\section{Notes:}

1. Gregory S. Blimling and Alfred S. Alschuler, "Curbing Epidemic Cheating Through Systemic Change," College Teaching 43, 4 (1995): 123-126.

2. David R. Johnson and David G. Post, "Law and Borders--The Rise of Law in Cyberspace," Stanford Law Review 48 (1996): 1367, <http://www.cli.org/X0025_ LBFIN. html> (27 January 2004).

3. See Internet Self-Regulation, <http://www.endispute.co.uk/cliff/israem.htm> (27 January 2004), and the extract of Matthew J. McCloskey, "Introduction to Bibliography of Internet Self-Regulation" (1998).

4. Gerard Noonan and Matthew Thompson, "Professor Guilty of Misconduct," The Sydney Morning Herald (24 December 2003), <http://www.smh.com.au/articles/2003/12/23/ 1071941728753.html?from=storyrhs $>$.

5. 'Cognition' means 'thinking about thinking.'

6. 'Rote learning' is repetitive learning, i.e. learning where our short-term memories were continually reinforced until we could flawlessly recite facts or figures (but did we know, or understand what we were regurgitating?)

7. Richard C. Atkinson and Richard M. Shiffrin, "Human Memory: A Proposed System and Its Control Processes," in The Psychology of Learning and Motivation, vol. 2, ed. Kenneth W. Spence and Janet T. Spence (New York: Academic Press, 1968), pp. 89195.

8. Guy R. Lefrancois, Psychology for Teaching, Seventh edition (Belmont: Wadsworth Publishing Company, 1991), p. 63. 
9. Lefrancois, Psychology for Teaching, p. 64.

10. Lefrancois, Psychology for Teaching, p. 69.

11. 'Metacognition' refers to 'knowing about knowing.'

12. 'Metamemory' refers to 'knowing about remembering.'

13. Judith R. Gordon, R. Wayne Mondy, Arthur Shaplin and Shane R. Premeaux, Management and Organizational Behavior (Boston: Allyn and Bacon, 1990), p. 521.

14. Australian Press Council Adjudication No.628 <http://www.austlii.edu.au/cgi-bin/disp. $\mathrm{pl} / \mathrm{au} /$ other/apc/628.html?query=\%7e+plagiarism $>$ (27 January 2004).

15. See the report by Ananova, Thai PM's son caught cheating in exams <http://www. ananova.com/news/story/sm_659940.html?menu=> (27 January, 2004).

16. Heather Bird, "The Law Won: Cheating on Exams Isn't a Mistake, It's a Character Flaw," Toronto Sun (3 May 2001), <http://www.geocities.com/CapitolHill/2381/ Lawschoolscase/ cheatingscanfaltosun.html> (27 January 2004).

17. "Cheating on Exams with Picture Phones," Straight Times (30 June 2003), <http://www. textually.org/picturephoning/archives/000982.htm> (27 January 2004).

18. "Maryland University students caught cheating by SMS," The Wall Street Journal (22 February 2003), Available at <http://www.textually.org/textually/archives/000026.htm> (28 January 2004).

19. See Article 1, Convention on the Rights of the Child (UN, 1989), <http://www.unhchr. $\mathrm{ch} / \mathrm{html} / \mathrm{menu} 3 / \mathrm{b} / \mathrm{k} 2 \mathrm{crc} . \mathrm{htm}>$ (12 April 2004).

20. In other jurisdiction this age has been lowered to 10 years of age, e.g. the State of New South Wales.

21. Lefrancois, Psychology for Teaching, p. 186.

22. Harold J. Noah and Max A. Eckstein, Fraud and Education - The Worm in the Apple (Lanham, MD: Rowman and Littlefield, 2001), p. 25.

23. John S. Croucher, Exam Scams: Best Cheating Stories and Excuses from Around the World (London: Allen and Unwin, 1997); Noah and Eckstein, Fraud and Education, p. 33.

24. ABC Perth, <http://www.abc.net.au/perth/stories/s411658.htm> (27 January 2004).

25. Noah and Eckstein, Fraud and Education, p. 21.

26. "Cheating and Succeeding: Record Numbers of Top High School Students Take Ethical Shortcut," 29th Annual Survey of High Achievers (1998), in Noah and Eckstein, Fraud and Education, p. 29.

See http://www.turnitin.com.

28. Meir Tamari, All I Need to Know about Business Dishonesty I Learned at School (Jerusalem: Business Ethics Center), <http://www.besr.org/library/dishonesty.html> (12 April 2004).

29. Rabbi Jay Kelman, Why People Cheat, <http://www.besr.org/library/whypeoplecheat. html> (14 April 2004).

30. Kelman, Why People Cheat.

31. Lisa Hinchcliffe, Cut-and-Paste Plagiarism: Preventing, Detecting and Tracking Online Plagiarism (May 1998), <http://alexia.lis.uiuc.edu/ janicke/plagiary.htm> (14 April 2004). 
32. Dennis Bricault, Legal Aspects of Academic Dishonesty: Policies, Perceptions, and Realities (March 1998), <http://campus.northpark.edu/esl/dishnst.html> (28 April 2004).

The New Webster Dictionary (1971), p. 140.

Bricault, Legal Aspects of Academic Dishonesty, p. 2.

Bulgarian Copyright Law, 2001.

Stewart Home, Neoism, Plagiarism and Praxis (Edinburgh: AK Press, 1995), p. 51.

Avoiding Plagiarism, Virtual Writing Center, <http://matcmadison.edu/is/writingcenter/ plagarism.htm> (15 November 2003).

Plagiarism: What It is and How to Recognize and Avoid It, Indiana University Bloomington Writing Tutorial Services, <http://www.indiana.edu/ wts/wts/plagiarism. html> (15 November 2003).

University Policy on Academic Honesty and Plagiarism, University of Melbourne, <http://www.services.unimelb.edu.au/plagiarism/policy.html>; See also Regulation 12.2.10, <http://www.unimelb.edu.au/ExecServ/Statutes/r12210r1.htm> (28 April 2004).

Excerpt from Queen's University Academic Regulation 26a in the 1999-2000 Arts and Science Calendar, <http://qsilver.queensu.ca/ hist121/plagaris.htm> (27 January, 2004).

I. Kirkwood, "Chiefs Set to Go," Newcastle and Hunter Herald (Saturday, 14 February 2004), p. $1 \&$ p. 4.

Kirkwood, "Chiefs Set to Go."

Kirkwood, "Chiefs Set to Go."

At the time of submission of this essay, the report by the St. James Ethics Centre had not been made public.

Julie J.C.H. Ryan, "Student Plagiarism in an On-line World," ASEE Prism Magazine (December 1998), <http://www.asee.org/prism/december/html/student_plagiarism_in_ an_onlin.htm> (28 April 2004).

'Turnitin.com' claims to be '...the world's leading online plagiarism prevention resource...' which offers '...innovative online learning products like Digital Portfolio and Peer Review.', <http://plagiarism.org/education.html> (27 January 2004).

$<$ http://plagiarism.org/education.html>.

Bruce H. Leland, Plagiarism and the Web, <http://www.wiu.edu/users/mfbhl/wiu/ plagiarism.htm> (29 January 2004).

Leland, Plagiarism and the Web.

<http://www.schoolsucks.com>

Access to http://www.ra-schoolsucks.com/cgi-bin/hazel-cgi/hazel.cgi?theme= schoolsucks\&action=serve \&item=schoolsucks/subjects.html\&refid=schoolsucks will show the huge array of subjects and the cost for the material..

Johnson and Post, "Law and Borders."

Jane C. Ginsburg, "Global Use/Territorial Rights: Private International Law questions of the Global Information Infrastructure," Journal of the Copyright Society of the USA 42, (1995): 318, 319-320; as quoted in Johnson and Post, "Law and Borders," p. 10.

'Copyright' is the intangible property which allows the copyright owner, or those authorised by the copyright owner, the exclusive right to prohibit, or to do certain acts. The rights comprised in copyright are distinct from any rights adhering in the medium in, 
or upon which the relevant work or subject matter is recorded. See Peter E. Nygh, ed., Butterworths Concise Australian Legal Dictionary (Sydney: Butterworths, 1997), p. 91.

55. Nygh, Butterworths Concise Australian Legal Dictionary, p. 91.

56. Bulgarian Copyright Law, 2001.

57. Nicholas Dilanchian, How Much Can You Copy, undated, <http://www.dilanchian.com. au> (15 November 2003).

58. Dilanchian, How Much Can You Copy, p. 2.

59. Johnson and Post, "Law and Borders," p. 10.

60. McCloskey, "Introduction to Bibliography of Internet Self-Regulation."

61. The international law of 'Comity' concerns that body of rules developed in international law by which the courts of a State demonstrate respect for the rules, customs and laws of another State. Non-observance of comity does not give rise to strict legal consequences, however, the State affected by the non-observance may reciprocate by retracting its own courteous practices. See Nygh, Butterworths Concise Australian Legal Dictionary, p. 70.

62. Dow Jones \& Company Inc. v Gutnick [2002] HCA 56 (10 December 2002).

63. Brian Fitzgerald, "Dow Jones \& Co Inc v Gutnick: Negotiating 'American Legal Hegemony' in the Transnational World of Cyberspace," Melbourne University Law Review 21 (2003), p. 590, <http://www.austlii.edu.au/cgi-bin/disp.pl/au/journals/MULR/ 2003/21.html?query=\%7e+dow+jones+and+gutnick> (14 April 2004).

64. The Wall Street Journal, <http://online.wsj.com/public/us〉.

65. Fitzgerald, "Dow Jones," p. 14.

66. Dilanchian, How Much Can You Copy, p. 4.

67. Noah and Eckstein, Fraud and Education, pp. 136-141.

68. Noah and Eckstein, Fraud and Education.

69. 'Pedagogy' is the art and science of teaching, or education. See Nygh, Butterworths Concise Australian Legal Dictionary, p. 1584.

70. The notion of 'Andragogy' concerns specific needs related to 'adult learning.' See Stephen D. Brookfield, Understanding and Facilitating Adult Learning: A Comprehensive Analysis of Principles and Effective Practices (San Francisco, CA; Jossey Bass Publishers, 1986), pp. 121-122.

71. Noah and Eckstein, Fraud and Education.

72. The Teaching and Learning Centre, Learning Contracts (Perth: University of Western Australia, 2000).

73. Blooms Taxonomy of Learning referred to a cognitive domain which commenced at 'Knowledge, Comprehension and Application' and rose to 'Analysis, Synthesis and Evaluation' - see Lefrancois, Psychology for Teaching, p. 370.

Lefrancois, Psychology for Teaching, p. 374. 
MATTHEW FAWKNER is an Australian lawyer and educationalist who has worked with many international organisations and educational institutions primarily in the disciplines of International Humanitarian Law and Human Rights. During his time with the George C. Marshall European Center for Security Studies he developed two distance learning courses which were accessed through the Partnership for Peace (PfP) Consortium Learning Management System. It was during this time that Matthew established an association with the PfP Advanced Distributive Learning Working Group, a connection which he maintains today. Matthew is not an expert in Cyberlaw, nor does he practice in that field. Any questions or discussion points may be addressed to him at: pathfinders@ hunterlink.net.au.

GRETA KEREMIDCHIEVA is the Head of English and French Department at Rakovski Defense and Staff College, Sofia, Bulgaria, where she practices as an educationalist, cognitive scientist and mentor. She has specialised methodology and management of language training in the USA, UK and other European countries. Greta excels in the field of 'adult education' where she is considered a leader in this specialist field. She possesses a deep interest in the area of the 'psychology of learning' and the general conception of 'why adult learners learn?'. 